\title{
47.4. ISOTOPIC EVIDENCE OF CHANGES IN OCEANIC CIRCULATION
}

\author{
A. Longinelli, Laboratory of Nuclear Geology, University of Pisa, Pisa, Italy \\ and \\ M. B. Cita, Institute of Paleontology, University of Milan, Milan, Italy
}

\section{INTRODUCTION}

During the last two decades or so, a number of papers have been published on the oxygen isotopic composition of the calcium carbonate in marine fossils of various ages. The main purpose of these measurements was to evaluate the growth temperature of the fossil shells, using the carbonate-water isotopic temperature scale determined experimentally by Epstein et al. (1953). This method has been used extensively on both macro- and micro-fossils. With regard to foraminifera, well known papers by Emiliani and co-workers led to the construction of a paleoclimatic curve, based on the isotopic study of planktonic species, which clearly indicated the sequence of glacial and interglacial periods during the Quaternary. The climatic significance of the curve is not in doubt, although the real meaning of the isotopic measurements in terms of temperature (and not only in the case of Quaternary fossils) has been questioned by various authors (Shackleton, 1968; Olausson, 1965; Duplessy et al., 1970; Longinelli, 1966; Longinelli and Nuti, 1968).

These criticisms were mainly based on two points: (a) the lack of knowledge of the oxygen isotopic composition of the ocean waters in the geological past, and (b) the possibility that oxygen isotope exchange took place between the carbonate of the fossils and ground water after sedimentation under different conditions of temperature and pressure than existed during the growth of the shell.

It is not possible to discuss here in detail these two points; however, it would be helpful to give a brief summary of the present state of research in this field in order to obtain a better understanding of the results reported here.

\section{Changes in the Isotopic Composition of Oceanic Water}

The problem of not knowing the isotopic composition of oceanic water during the past was temporarily solved by assuming there were no major variations of the oxygen isotopic composition of ocean water during the last 200 to 250 my. Yet this assumption obviously does not hold true for even the Quarternary.

Several authors have not agreed with the above assumption and suggested instead the possibility of a progressive depletion in $\mathrm{O}^{18}$ in sea water going back in time (Silverman, 1951; Craig, 1965; Longinelli, 1966; Longinelli and Nuti, 1968). With regard to the Quaternary, Emiliani (1955) has attempted to evaluate the possible variation of the isotopic composition of oceanic water between glacial and interglacial periods; however, Dansgaard and Tauber (1969) and other authors have disputed his conclusions, mainly on the basis that the isotopic composition of ice from the Greenland ice cap cores is much more negative during glacial periods than that evaluated by Emiliani for his calculation. Unfortunately, at the present state of research, it is not possible to arrive at a definite conclusion regarding this problem. This means that all isotopic measurements on fossils must be considered very cautiously, always taking into account the fact that incertitude concerning the isotopic composition of oceanic water creates a similar incertitude in the interpretation of the results obtained.

\section{Changes Due to Isotopic Exchange}

With regard to point (b), the possibility of oxygen isotope exchange readily taking place between calcium carbonate and water was demonstrated by Deuser and Degens (1969). They measured the isotopic composition of foraminifera and pteropoda found in cores taken from the deep hot-brine area of the central Red Sea and proved that contact between the shells and the hot brine lasting about 3000 years was sufficient to cause a large isotopic exchange. The temperature and pressure values were about $50^{\circ} \mathrm{C}$ and about two hundred atmospheres. One could object that in the case of Tertiary and Quaternary marine sediments which have been buried in the bottom of the ocean from the time of their deposition, while pressure conditions were of the same order of magnitude, temperature conditions were far from the Red Sea brine values. However, concerning Upper Tertiary fossils, the higher time coefficient can be of some importance, despite relatively low temperatures, in favoring at least a partial oxygen isotope exchange.

The above considerations show that the interpretation of isotopic results can be by no means simple or straightforward, and that it is advisable to consider the results in terms of oxygen isotopic composition and not in terms of temperature values. This has recently also been done by Emiliani (1971). It is obvious that the older the fossils are the greater is the uncertainty in interpreting the isotopic results obtained.

\section{SAMPLES MEASURED AND TECHNIQUES USED}

In spite of the above difficulties in obtaining a correct interpretation of the isotopic data, we decided to measure a group of samples separated from cores recovered at two drill sites in the Mediterranean with more or less continuous sections through the Pliocene, in the hope of confirming the inferred paleoclimatic curve discussed in Chapter 47.3. The isotopic measurements were made by one of us (A.L.) on selected foraminiferal tests of only one species of planktonic foraminifer (Orbulina universa). This species was selected because (1) it was the only one sufficiently abundant to obtain the required amount of tests from a sediment fraction of about $5 \mathrm{cc}$., and (2) it is sensitive to temperature changes. The disadvantage of using Orbulina universa is the fact that its depth habitat is not well known. 
According to Emiliani (1954), Orbulina can be found at depths exceeding 100 meters. If so, it is obvious that relatively small temperature variations influencing only the superficial layer of the ocean might not be "isotopically recorded" by Orbulina specimens.

Only adult, fully-developed specimens of Orbulina universa, the largest of the entire assemblages, were isolated in order to obtain a good homogeneity of the samples. The samples were processed following the technique described by Epstein et al. (1953). They were repeatedly washed in distilled water, dried at $90^{\circ} \mathrm{C}$, and crushed and powdered in an agate mortar. The powdered samples were roasted for about 15 minutes at $450^{\circ} \mathrm{C}$ under helium flux in order to pyrolize the organic matter and then reacted in a vacuum at $25.3^{\circ} \mathrm{C}$ with 100 percent phosphoric acid. The $018 / 016$ and $\mathrm{C} 13 / \mathrm{C} 12$ ratios of the $\mathrm{CO}_{2}$ obtained were measured using an Atlas M 86 mass spectrometer, against a working $\mathrm{CO}_{2}$ standard obtained by reacting a very pure white Carrara marble whose isotopic composition is - $1.60(018 /$ $\mathrm{O} 16)$ and $+2.49\left(\mathrm{C}^{13} / \mathrm{C}^{12}\right)$ with phosphoric acid (PDB-1 Chicago standard). The average reproducibility $(\delta)$ is \pm 0.1 per mil.

Both the external and the internal surface of the tests were generally very clean. Occasionally, tests contained some clay, and in this case the crushed tests were repeatedly washed with distilled water and treated in an ultrasonic bath until they were perfectly clean. Some of the tests in a few samples from Site 132 showed a yellowish film of secondary calcite covering the internal surface of the chambers. Treatment in an ultrasonic bath generally succeeded in removing this secondary material. Fragments which were not perfectly clean were discarded. A few samples were large enough to be measured twice. Only one measurement was made on samples weighing 5 to $9 \mathrm{mg}$.

Criticisms may be made about the roasting treatment. Emiliani (1966) found that, in the case of living foraminifera, roasting under helium flux yielded values reasonably close to those obtained by roasting in a vacuum. Currently, several authors simply treat samples with commercial Clorox. Roasting under helium flux was preferred in this case because this has been the treatment used in the Laboratory of Nuclear Geology in Pisa since the very beginning of isotopic work. Moreover, since this procedure was used to determine experimentally the carbonate equation (Epstein et al., 1953), it seemed advisable to keep using the technique which had been applied for years to paleotemperature work on both macro- and microfossils. By doing so, we could achieve a better comparison among the isotopic data of various investigators.

\section{PRELIMINARY RESULTS}

The isotopic results obtained are reported in Tables 1 and 2, along with the coefficients of the "Globigerinoides curve" in each sample (the inferred climatic curve discussed in Chapter 47.3, Part 3). It is apparent that no obvious correlations exist between these two variables. For instance, at Site 125 , the lowest values of $\delta 018(+0.92$ and +0.89$)$ have been observed in samples whose "Globigerinoides
TABLE 1

Stable Isotopic Data Obtained from the Analysis of Sites 125 and 125A (Ionian Basin) Samples (Orbulina universa)

\begin{tabular}{|c|c|c|c|c|c|c|}
\hline Core & Section & $\begin{array}{l}\text { Distance } \\
\text { From Top } \\
\text { (cm) }\end{array}$ & $\delta \mathrm{O}^{18}$ & $\delta \mathrm{C}^{13}$ & $\begin{array}{l}\text { Coeff. of } \\
\text { Gb. Curve }\end{array}$ & Age \\
\hline \multicolumn{7}{|c|}{ Site 125} \\
\hline & 4 & $133-135$ & +1.60 & +2.19 & 3 & \multirow{8}{*}{ 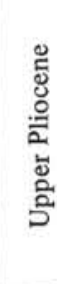 } \\
\hline 4 & 5 & $105-107$ & +1.57 & +2.00 & 4 & \\
\hline & 6 & $146-148$ & +1.40 & +2.42 & 3 & \\
\hline \multirow{3}{*}{5} & 1 & $1-4$ & +0.92 & +1.90 & 4 & \\
\hline & 2 & $76-79$ & +1.13 & +2.00 & 1 & \\
\hline & 3 & $75-78$ & +1.19 & +2.03 & 2 & \\
\hline \multirow[b]{2}{*}{6} & 1 & $99-102$ & +0.89 & +1.93 & 3 & \\
\hline & 3 & $61-64$ & +1.55 & +2.05 & 1 & \\
\hline
\end{tabular}

\begin{tabular}{|c|c|c|c|c|c|c|}
\hline \multicolumn{7}{|c|}{ Site $125 \mathrm{~A}$} \\
\hline 1 & $\begin{array}{c}1 \\
2 \\
\mathrm{CC}\end{array}$ & $\begin{array}{l}71-74 \\
40-42\end{array}$ & $\begin{array}{l}+0.71 \\
+1.44 \\
+1.13 \\
\end{array}$ & $\begin{array}{l}+2.01 \\
+2.50 \\
+1.92 \\
\end{array}$ & $\begin{array}{l}3 \\
4 \\
2 \\
\end{array}$ & 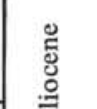 \\
\hline 2 & $\begin{array}{c}1 \\
2 \\
\mathrm{CC}\end{array}$ & $\begin{array}{l}72-74 \\
25-28\end{array}$ & $\begin{array}{l}+1.40 \\
+0.99 \\
+1.14 \\
\end{array}$ & $\begin{array}{l}+2.36 \\
+2.00 \\
+2.10\end{array}$ & $\begin{array}{l}1 \\
4 \\
2\end{array}$ & $\begin{array}{l}\bar{a} \\
\text { s } \\
\text { م. } \\
\vdots\end{array}$ \\
\hline 5 & $\begin{array}{l}1 \\
2 \\
4\end{array}$ & $\begin{array}{r}108-111 \\
99-102 \\
122-124\end{array}$ & $\begin{array}{l}+1.34 \\
+0.13 \\
+0.63\end{array}$ & $\begin{array}{l}+1.52 \\
+1.45 \\
+2.06\end{array}$ & $\begin{array}{l}3 \\
2 \\
3\end{array}$ & 岂方 \\
\hline
\end{tabular}

TABLE 2

Stable Isotopic Data Obtained from the Analysis of Site 132 (Tyrrhenian Basin) Samples (Orbulina universa)

\begin{tabular}{|c|c|c|c|c|c|c|}
\hline Core & Section & $\begin{array}{l}\text { Distance } \\
\text { From Top } \\
(\mathrm{cm})\end{array}$ & $\delta^{18}$ & $\delta^{13}$ & $\begin{array}{l}\text { Coeff. of } \\
\text { Gb. Curve }\end{array}$ & Age \\
\hline 8 & $\begin{array}{l}5 \\
6 \\
\end{array}$ & $\begin{array}{r}97-99 \\
40-43 \\
\end{array}$ & $\begin{array}{l}+1.11 \\
-0.83 \\
\end{array}$ & $\begin{array}{l}+1.54 \\
+2.40 \\
\end{array}$ & $\begin{array}{l}3 \\
1 \\
\end{array}$ & \multirow{6}{*}{ 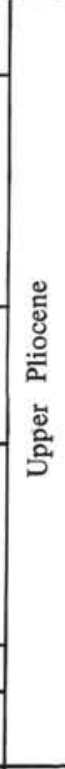 } \\
\hline 10 & $\begin{array}{c}1 \\
2 \\
3 \\
4 \\
5 \\
6 \\
\text { CC }\end{array}$ & $\begin{array}{l}35-37 \\
35-37 \\
35-37 \\
35-37 \\
35-37 \\
35-37\end{array}$ & $\begin{array}{l}+1.11 \\
+1.35 \\
+0.78 \\
+1.32 \\
+0.79 \\
+0.60 \\
+0.26\end{array}$ & $\begin{array}{l}+2.30 \\
+2.18 \\
+2.14 \\
+2.14 \\
+1.95 \\
+1.62 \\
+2.06\end{array}$ & $\begin{array}{l}3 \\
2 \\
1 \\
1 \\
2 \\
1 \\
3\end{array}$ & \\
\hline 11 & $\begin{array}{c}1 \\
2 \\
3 \\
\mathrm{CC} \\
\end{array}$ & $\begin{array}{l}35-37 \\
35-37 \\
80-82\end{array}$ & $\begin{array}{l}+1.01 \\
+0.95 \\
+0.23 \\
+0.78 \\
\end{array}$ & $\begin{array}{l}+1.85 \\
+2.02 \\
+1.91 \\
+1.82 \\
\end{array}$ & $\begin{array}{l}1 \\
1 \\
1 \\
2 \\
\end{array}$ & \\
\hline 12 & $\begin{array}{l}1 \\
2 \\
3 \\
4 \\
5 \\
6 \\
\end{array}$ & $\begin{array}{l}35-37 \\
35-37 \\
40-42 \\
35-37 \\
35-37 \\
35-37 \\
\end{array}$ & $\begin{array}{l}+0.94 \\
+1.20 \\
+0.70 \\
+0.47 \\
+1.20 \\
+1.70 \\
\end{array}$ & $\begin{array}{l}+2.01 \\
+2.00 \\
+1.83 \\
+2.20 \\
+2.08 \\
+1.85\end{array}$ & $\begin{array}{l}2 \\
2 \\
1 \\
2 \\
2 \\
2 \\
\end{array}$ & \\
\hline 13 & 4 & $35-37$ & +0.26 & +1.80 & 2 & \\
\hline 14 & $\begin{array}{l}2 \\
3 \\
\end{array}$ & $\begin{array}{c}35-37 \\
115-117 \\
\end{array}$ & $\begin{array}{l}+0.73 \\
+0.61 \\
\end{array}$ & $\begin{array}{l}+2.20 \\
+1.11 \\
\end{array}$ & $\begin{array}{l}2 \\
2 \\
\end{array}$ & \\
\hline 15 & $\begin{array}{l}3 \\
4 \\
6 \\
\end{array}$ & $\begin{array}{l}35-37 \\
35-37 \\
35-37 \\
\end{array}$ & $\begin{array}{r}+0.55 \\
+1.16 \\
0.00 \\
\end{array}$ & $\begin{array}{l}+1.68 \\
+1.75 \\
+1.58 \\
\end{array}$ & $\begin{array}{l}2 \\
2 \\
3 \\
\end{array}$ & \multirow{4}{*}{ 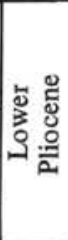 } \\
\hline 16 & 4 & $35-37$ & +1.16 & +1.94 & 1 & \\
\hline 17 & 4 & $35-37$ & +0.88 & +1.85 & 1 & \\
\hline 18 & 4 & $35-37$ & +0.23 & +1.42 & 1 & \\
\hline
\end{tabular}


curve" coefficients ${ }^{1}$ are, respectively, 4 and 3 . A very positive value of $\delta \mathrm{O}^{18}(+1.55)$ has been obtained from a sample with a Globigerinoides coefficient of 1 . Other samples show either no correlation or positive correlation between parameters which, assuming that changes in the isotopic composition are caused by changes of water temperature, should be negatively correlated. The results obtained may be briefly summarized as follows:

\section{Hole 125 - Mediterranean Ridge, Ionian Basin}

Eight samples were analysed for the determination of the $\mathrm{O}^{18 / 0} / \mathrm{O}^{6}$ and $\mathrm{C} 13 / \mathrm{C}^{12}$ ratios in the carbonate of Orbulina universa tests. All the studied samples belong to the Upper Pliocene, "orange," "green," and "yellow" climatic episodes (see Figure 5 of Chapter 47.3). Both the $\delta \mathrm{O}^{18}$ and the $\delta \mathrm{C} 13$ values are rather positive: $\delta \mathrm{O}^{18}$ range from +0.89 to +1.60 , the average value being $+1.28 ; \delta \mathrm{C} 13$ range from +1.90 to +2.24 , the average value being +2.06 .

\section{Hole 125A - Mediterranean Ridge, Ionian Basin}

Nine samples have been studied, seven of which can be referred to the Upper Pliocene, two to the Lower Pliocene, "orange," "green," and "red" climatic episodes. The isotopic values are again rather positive: $\delta 018$ range from +0.13 to +1.44 , the average value being $+0.99 ; \delta \mathrm{C}^{13}$ range from +1.45 to +2.50 , the average value being +1.99 .

In this group of samples, the lowest isotopic composition of both oxygen and carbon was found in a sample $(125 \mathrm{~A}, 5-2 ; 99-102 \mathrm{~cm})$ which is just at the Lower Pliocene-Upper Pliocene boundary.

\section{Hole 132 - Tyrrhenian Basin}

Of the twenty eight samples studied, twenty-two are from sediments referred to the Upper Pliocene and six from the Lower Pliocene. All the climatic episodes ("orange," "green," "yellow," "brown," "red") are represented in the samples measured. All the $018 / 016$ values are positive, except one which, surprisingly, is negative $(-0.83)$. This sample comes from the topmost part of the section (Core $8-6,40-43 \mathrm{~cm})$, just beneath the Pliocene-Pleistocene boundary, and could not be rerun because of lack of material. If we disregard this single measurement, the $\delta \mathrm{O}^{18}$ values range from 0.00 (Lower Pliocene, Core 132-15-6; $35.37 \mathrm{~cm})$ to +1.70 , the average value being +0.81 . The $\delta \mathrm{C}^{13}$ values range from +1.11 to 2.40 , the average value being +1.90 .

\section{DISCUSSION}

First of all, it must be pointed out that isolated measurements on samples separated by intervals of about 1 meter cannot be expected to yield a good picture of climatic variations with time. On the other hand, average values calculated from samples of different age have limited significance and must be considered very cautiously. The isotopic values obtained from the samples of Holes 125 and

\footnotetext{
${ }^{1}$ A low Globigerinoides coefficient corresponds to cool climate whereas a low value of $\delta 0^{18}$, if interpreted in terms of temperature, would indicate a warm climate.
}

$125 \mathrm{~A}$ are rather close to one another. This is reasonable since both drill holes are located at the same site on the Mediterranean Ridge in the eastern Mediterranean. The lower average values obtained for Hole 125A evidently result from the fact that, in this case, one of the two samples of Lower Pliocene age studied yielded the lowest isotopic values $\left(\delta \mathrm{O}^{18}=+0.13 ; \delta \mathrm{C}^{13}=+1.45\right)$ recorded in these cores. The $\delta \mathrm{O}^{18}$ values recorded at Site 132 are definitely lower than those recorded for Holes 125 and $125 \mathrm{~A}$. This is an important point because: (a). Site 132 is located in the Tyrrhenian Basin, at a latitude about 5 degrees higher than that of Site 125 , which is located in the Ionian Basin. Lower temperatures of the superficial layer of water at Site 132 are expected to cause $\mathrm{O}^{18} / \mathrm{O}^{16}$ ratios to be more positive than those recorded at Site 125. (b) Paleontological evidence indicates that, during the Pliocene, the climate was warmer in the Ionian Basin (Holes 125, 125 A) than in the Tyrrhenian Basin (Hole 132). The faunal diversity is greater in the former. Species of tropical Globorotaliae occur, e.g., G. menardii, which have not been recorded in the Tyrrhenian and Globoquadrina altispira, which is a warm water species, is more abundant in the Ionian cores than in the Tyrrhenian ones. The "Globigerinoides curve" itself clearly suggests that the superficial water in the eastern Mediterranean was warmer than water in the western Mediterranean. Thus, the observed isotopic results are exactly opposite to what one would expect them to be if they were controlled by temperature alone.

Moreover, it must be noticed that the $\delta \mathrm{O}^{18}$ recorded by Upper Pliocene samples are more positive than those recorded by Lower Pliocene samples, indicating Upper Pliocene lower temperatures. Paleontological evidence leads to opposite conclusions.

$\delta \mathrm{C}^{13}$ values are generally positive, and average values in the three wells are rather close to one another. In Hole 132 the values are perhaps a little bit more negative than the values in Holes 125 and $125 \mathrm{~A}$. The seven oldest samples from Hole 132 definitely show an average $\delta C^{13}$ (about +1.60 ) more negative than that of any other group of samples. This difference parallels the already mentioned similar variation of the oxygen isotopic composition in the same samples. Six out of these seven samples have been assigned to the Lower Pliocene on the grounds of paleontological considerations.

\section{INTERPRETATION OF RESULTS}

Since there is no apparent correlation between the isotopic values and climatic variations as shown by the "Globigerinoides curve," consideration must be given to the possible influence of variables other than temperature on the isotopic values of the studied samples.

\section{An Evaluation of the Possibility of Isotopic Exchange}

First of all, consideration should be given to the possibility that post-depositional isotope exchange processes can contribute to altering the original isotopic values. Although one can easily accept the possibility that some exchange has taken place in the studied material after burial, it seems improbable that large changes in the $018 / 016$ ratios affected the foraminiferal shells investigated here. In fact, the material is relatively young in terms 
of geologic age and has not been buried at great depths. This means that the temperature of the buried sediments was not very far from the growth temperature of the tests and that, probably, the oxygen isotopic composition of the interstitial water trapped within the sediments was also not very far from that of the water in which the foraminifera lived. However, isotope exchange effects can be of some importance in the case of Lower Pliocene samples.

\section{Natural Isotopic Gradients within the Basins}

The $018 / 016$ ratio in modern Mediterranean water is more positive than that of the Atlantic water at the latitude of the Strait of Gibraltar. From the time of the very first paper on this subject by Epstein and Mayeda (1953), it was found that a marked difference exists between the eastern and the western Mediterranean basins. In a general way, the $\mathrm{O}^{18} / \mathrm{O}^{16}$ ratio in the Mediterranean water shows a trend similar to that of surface salinity. Increasing from west to east, the $018 / 016$ ratios in the western Mediterranean range from about +0.7 per mil (vs. SMOW as defined by Craig (1961)) to +1.2 per mil. In the eastern Mediterranean, the $018 / 016$ ratio is definitely higher, reaching values of +1.6 and above. The differences are mainly due to climatic factors such as insolation and the excess of evaporation over precipitation. In addition, as the surface water from the Atlantic enters the Mediterranean and moves eastward, it keeps its autonomy and does not mix well with the subadjacent water masses. Thus what it loses to the atmosphere is not readily gained back from other reservoirs.

\section{Past Variations in the Isotopic Composition}

The possibility of unknown variations in the isotopic composition of the Mediterranean waters in the past remains a problem. It is obvious that during the glacial Pleistocene the isotopic composition changed with each waxing and waning of the great ice sheets. The growth of glaciers on the continents would preferentially enrich the oceans in $\mathrm{O}^{18}$, whereas the melting would increase the relative $\mathrm{O}^{16}$ budget. The composition of the Mediterranean would not only be expected to vary with time, but might show large lateral differences; the result of certain basins receiving greater melt water than others.

Although it is difficult to advance hypotheses regarding isotopic compositional changes for the preglacial Pleistocene and the Pliocene, some data are available. For instance, Longinelli and Nuti (1968), on the basis of oxygen isotope measurements carried out on the phospate in Upper Tertiary fossils, have suggested that a major depletion in the $\mathrm{O} 18$ of Mediterranean water took place from Miocene to Pliocene times. The cause is not entirely understood, but is perhaps related to the extensive formation of evaporites throughout the Mediterranean in the late Miocene (see Chapter 43) leading to an 018 excess followed by a sudden replacement of normal marine conditions in the Lower Pliocene.

\section{The Effects of Sills and Barriers}

Only a rather weak vertical circulation is present in today's deep basins of the Mediterranean Sea. Though the turnover is more than adequate to keep the local bottom water masses ventilated with oxygen, it has not led to an active lateral circulation of the bottom waters.

However, many lines of evidence indicate that this has not always been the case. For instance, drilling at every site in the western Mediterranean has revealed sedimentological evidence of reworking and non-deposition in the marine sediments which can only be explained by the presence of a vigorous circulation across the sea bed. The periods of greatest erosion leading to major hiatuses at Sites 121, 122, 123,124 , and 134 occurred in the Lower Pliocene. Because the seismic reflection profiles (discussed in Chapter 37) indicate several widespread erosional surfaces in the postevaporitic successions (which correlate at the drilling sites to the gaps in sedimentation and the presence of hardgrounds) it has been suggested by others in this volume that the near sea floor current regimes were part of a basinwide geostrophic circulation system with passage to and from the open Atlantic Ocean. This conclusion was corroborated by the discovery (see Chapter 36.1) of psychrospheric ostracods exclusive to the Pliocene and Lower Pleistocene deep-sea sediments of Sites 134 (Balearic Abyssal Plain) and 132. Their presence implies cold bottom temperatures $\left(<6^{\circ} \mathrm{C}\right)$, possible only by the influx of North Atlantic deep-water (Benson, 1971).

Though we only twice cored the Pliocene succession in the eastern Mediterranean (Holes 125 and 125A), and consequently our evidence is not as clear as for the Balearic Basin, we never did find an indication of submarine erosion conclusively related to bottom currents. This is well understood if we consider that a shallow sill, slightly more than 200 meters deep, separates Sicily and Tunisia and prevents a deep connection between the eastern and western basins. No species of psychospheric ostracods were found in the core samples of Site 125 .

Moreover, we found evidence of periodic stagnation in the Upper Pliocene sediments of the Ionian Basin (sapropels recorded in Core 2 of Site 125A, lower part of the "green" paleoclimatic episode). Stagnations and active, oceanic-type bottom currents are obviously exclusive of each other.

The existence of deep geostrophic currents in the western Mediterranean implies the possibility of a dilution of an isotopically heavy Mediterranean water with isotopically lighter Atlantic water. It also implies the possibility of isotopic gradients between eastern and western Mediterranean Basins, similar or even higher than present day gradients. This hypothesis is supported by comparison of the isotopic analyses. The average value from the Tyrrhenian Basin cores is more negative than the average value of the Ionian Basin cores by about 0.5 per mil. This is contrary to what we would instinctively expect from temperature considerations alone. ${ }^{2}$

${ }^{2}$ These two conditions have opposite effects on the isotopic composition of the carbonate precipitated under isotopic equilibrium conditions: a relatively low temperature of precipitation (Site 132 is $5^{\circ}$ north of Site 125 ) tends to enrich the carbonate in $0^{18}$, while the addition of negative environmental water (mixing from the Atlantic) tends to deplete the carbonate in $0^{18}$ and vice versa. 


\section{CONCLUSIONS}

It is not simple to draw conclusions from the absolute values of the preliminary isotopic measurements. The situation is, quite likely, further complicated by the anomalous situation caused by Upper Miocene evaporitic conditions. We cannot define the exact influence of the addition of Atlantic water during the Pliocene since we know neither the temperature of, nor the isotopic gradients between, Atlantic and Mediterranean water at that time. We are also unable to evaluate quantitatively the variation with time of the influx of Atlantic water.

Nevertheless, we can offer some tentative conclusions. The role of mixing of Atlantic and Mediterranean waters has been important. The eastern Mediterranean basins have remained distinctly more isolated than the western basins. The evolution of the isotopic ratios toward more positive values in the Upper Pliocene probably reflects a gradual constriction of a Gibraltar portal that was deep in lowermost Pliocene times, rather than a trend towards colder climatic conditions, which are unsupported in the faunal analyses of Chapter 47.3 . $^{3}$

In spite of the fact that only a random correlation exists between the "Globigerinoides curve" and the isotopic results obtained, there is no conflict between the general picture of the climatic evolution, as supported in the faunal analyses, and changes in the oceanic circulation in the Mediterranean brought about by the opening and closing of a deep passageway to the Atlantic Ocean. The interpretation of the isotopic data from Orbulina universa fits this picture well and agrees with the hypothesis of large variations of the isotopic composition of Mediterranean sea water proposed by Longinelli and Nuti (1968), brought about by a complex spectrum of natural causes.

\section{REFERENCES}

Benson, R. H., 1971. Ostracodes as indicators of threshold depth in the Mediterranean during the Pliocene. Proc. VII International Cong. Sedimentol. Heidelberg.

\footnotetext{
${ }^{3}$ It must be pointed out that the results obtained from Upper Pliocene Orbulina universa samples from Site 125 are rather close to the results obtained by Emiliani et al. (1961) and by Emiliani (1971) from Upper Pliocene Globigerina bulloides samples which came from the Pliocene-Pleistocene section at Le Castella, Calabria, Italy, and which showed no marked cooling at the stratigraphic boundary.
}

Craig, H., 1961. Standard for reporting concentrations of deuterium and oxygen-18 in natural waters. Science. $133,1833$.

, 1965. The measurement of oxygen isotope paleotemperatures. Stable isotopes in Oceanographic studies and Paleotemperatures. Tongiorgi, E., (Editor). 161.

Deuser, W. G. and Degens, E. T., 1969. O18/016 and $\mathrm{C}^{13} / \mathrm{C}^{12}$ ratios of fossils from the hot-brine deep area of the central Red Sea. In: Hot brines and recent heavy metal deposits in the Red Sea, Degens, E. T., and Ross, D. A. (Editors), Springer-Verlag.

Dansgaard, W. and Tauber M., 1969. Glaciers oxygen-18 content and Pleistocene ocean temperatures. Science. $166,499$.

Duplessy, J. C., Lalou, C and Vinot, A. C., 1970. Differential isotopic fractionation in benthic foraminifera and paleotemperatures reassessed. Science. 168, 250.

Emiliani, C., 1954. Depth habitat of some species indicated by oxygen isotope ratios $A m$. J. Sci. 252, 149.

1955. Pleistocene temperatures, J. Geol. 63, 538.

1966. Paleotemperature analyses of Caribbean cores P6304-8 and P6304-9, and a generalized temperature curve for the past 425,000 years. J. Geol. 74, 109.

1971. Paleotemperature variations across the Plio-Pleistocene boundary. Science. 171, 60.

Emiliani, C., Mayeda, T. and Selli, R., 1961. Paleotemperature analysis of the Plio-Pleistocene section at Le Castella, Calabria, Southern Italy. Bull. Geol. Soc. Am. 72, 679 .

Epstein, S., Buchsbaum, R., Lowenstam, H. A. and Urey, H. C., 1953. Revised carbonate-water isotopic temperature scale. Bull. Geol. Soc. Am. 64, 1315.

Epstein, S. and Mayeda, T., 1953. Variations of the $\mathrm{O} 18$ content of waters from natural sources. Geochim. Cosmochim Acta. 4, 213.

Longinelli, A., 1966. Ratios of oxygen-18: oxygen-16 phosphate and carbonate from living and fossil marine organisms. Nature. 211, 923.

Longinelli, A. and Nuti, S., 1968. Oxygen-isotope ratios in phosphate from fossil marine organisms. Science. 160, 879.

Olausson, E., 1965. Evidence of climatic changes in north Atlantic deep-sea cores, with remarks on isotopic paleotemperature analysis. Progress in Oceanography. 3, 221.

Shackleton, N. J., 1968. Depth of pelagic foraminifera and isotopic changes in Pleistocene oceans. Nature. 281, 79.

Silverman, S. R., 1951. The isotopic geology of oxygen. Geochim Cosmochim. Acta. 4, 26. 